\title{
Mechanical Erosion in a Tropical River Basin in Southeastern Brazil: Chemical Characteristics and Annual Fluvial Transport Mechanisms
}

\author{
Alexandre Martins Fernandes, ${ }^{1}$ Murilo Basso Nolasco, ${ }^{1}$ \\ Christophe Hissler, ${ }^{2}$ and Jefferson Mortatti ${ }^{1}$ \\ ${ }^{1}$ Centro de Energia Nuclear na Agricultura, Universidade de São Paulo, Avenida Centenário, \\ 303, 13416-970 Piracicaba, SP, Brazil \\ ${ }^{2}$ Département Environnement et Agrobiotechnologies, Centre de Recherche Public Gabriel Lippmann, 41, \\ rue du Brill, Grand-Duchy of Luxembourg, 4422 Belvaux, Luxembourg
}

Correspondence should be addressed to Alexandre Martins Fernandes, afernandes@cena.usp.br

Received 29 March 2012; Revised 9 August 2012; Accepted 10 December 2012

Academic Editor: Steven L. Forman

Copyright (c) 2012 Alexandre Martins Fernandes et al. This is an open access article distributed under the Creative Commons Attribution License, which permits unrestricted use, distribution, and reproduction in any medium, provided the original work is properly cited.

This study aims to evaluate the mechanical erosion processes that occur in a tropical river basin, located in the São Paulo state, southeastern Brazil, through the chemical characterization of fine suspended sediments and the transport mechanisms near the river mouth, from March 2009 to September 2010. The chemical characterization indicated the predominance of $\mathrm{SiO}_{2}, \mathrm{Al}_{2} \mathrm{O}_{3}$, and $\mathrm{Fe}_{2} \mathrm{O}_{3}$ and showed no significant seasonal influences on the major element concentrations, expressed as oxides. The concentration variations observed were related to the mobility of chemical species. The evaluation of the rock-alteration degree indicated that the physical weathering was intense in the drainage basin. The fine suspended sediments charge was influenced by the variation discharges throughout the study period. The solid charge estimate of the surface runoff discharge was four times higher in the rainy season than the dry season. The transport of fine suspended sediments at the Sorocaba River mouth was $55.70 \mathrm{t} \mathrm{km}^{-2} \mathrm{a}^{-1}$, corresponding to a specific physical degradation of $37.88 \mathrm{~m} \mathrm{Ma}^{-1}$, a value associated with the mechanical erosion rate that corresponds to the soil thickness reduction in the drainage basin.

\section{Introduction}

The mechanical erosion processes that occur in a drainage basin tend to reduce the thickness of the soils and the volume of the bedrock, by which dislocated and degraded particles are exported by the rivers to the sedimentation areas (lakes and oceans). The sediment production, transport, and deposition at the drainage basin scale are principally controlled by natural processes that may be intensified due to human activities, mainly agriculture and urbanization [1]. It is now recognized that in areas where urbanization grew drastically during the last century, the contribution of urbanoriginated sediments to the suspended particulate matter of water bodies is significant [2].

Soil erosion and its impacts on agricultural productivity, water quality, and siltation in rivers and reservoirs have been frequently discussed with regard to sustainable management of the services that these ecosystems deliver to the population [3]. In this context, the knowledge of mechanical erosion processes that occur in a tropical river basin is of outmost importance. It is now essential to reduce the loss of surface soil layers in agricultural areas and to anticipate the accumulation of deposited sediments at the industrial/urbanized areas. The intensity of mechanical erosion in a drainage basin can be assessed by monitoring the fine suspended sediments (FSS) dynamic in a given period [2].

This study aims at evaluating the main aspects of the mechanical erosion processes that occur in the Sorocaba River basin, located in the São Paulo state, southeastern Brazil, through the chemical characterization of fine suspended sediments and mechanisms of river transport close 


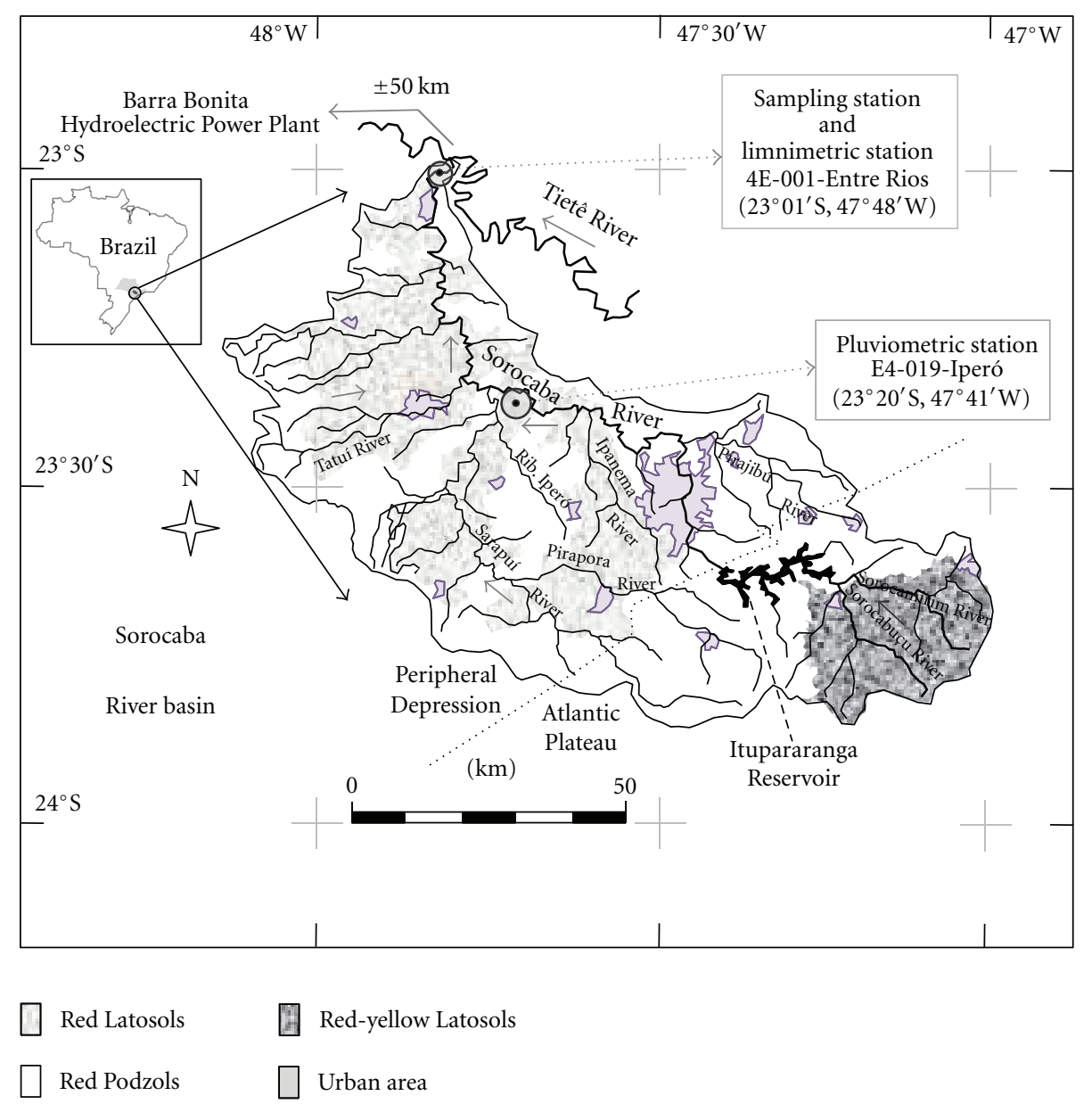

Figure 1: Drainage basin of the Sorocaba River with the location of the sampling station, near to the mouth, of the limnimetric station (4E-001-Entre Rios) and the pluviometric station (E4-019-Iperó). The main soils type, urban areas, and the division between Atlantic Plateau and Peripheral Depression (dotted line) are shown.

to its mouth, in the Laranjal Paulista city, from March 2009 to September 2010.

The knowledge of mechanical erosion processes that occur in the Sorocaba River basin is needed because the $50 \mathrm{~km}$ downstream of the confluence with the Tietê River is located the Barra Bonita Hydroelectric Power Plant Reservoir, and the change in the drainage system river system provided by the dam, from lotic to lentic, favors the processes of sediment deposition, which in turn affects the water storage capacity and the lifetime of the reservoir.

\section{Study Area}

The Sorocaba River, $227 \mathrm{~km}$ long, is the most important left bank tributary of the Middle Tietê River basin (Figure 1). It is located in the southeastern part of São Paulo state, between $23^{\circ}$ and $24^{\circ} \mathrm{S}$ parallels and $47^{\circ}$ and $48^{\circ} \mathrm{W}$ meridians, covering an area of $5,269 \mathrm{~km}^{2}$. This basin extends over 18 municipalities, with a total population of 1.2 million inhabitants, approximately [4].

The Sorocaba River basin is divided in two geomorphological units. The upstream part corresponds to the Planalto
Atlântico (Atlantic Plateau), and this headwaters region is situated in the morphological unit of the Plateau Ibiúna/São Roque, where high hills with acute and convex tops are predominant. The elevations range between 800 and $1000 \mathrm{~m}$ and steep slopes above $20 \%$. The lithology is represented by migmatites and granite, and the predominant soils are red-yellow Latosol and red Podzol. The downstream part of the basin is situated in the Depressão Periférica (Peripheral Depression), after Itupararanga Reservoir. This drainage basin area is located in the Depression of the Middle Tietê morphological unit, which presents a relief of hills with broad tabular and convex tops. The elevations range between 500 and $650 \mathrm{~m}$ and the slopes between $5 \%$ and $10 \%$. The lithology is represented by diabases and sandstones, and the soils are red Latosols and red Podzols [5-7].

The drainage system of the Sorocaba River basin is dendritic pattern, and drainage density has a potential fragility from medium to high, an important morphometric parameter of analysis in hydrographic basins related to erosion susceptibility [6]. Most of the original vegetation, characterized by woods, barns, fields, savanna-type grasslands, and wetlands, has been replaced by agriculture and urban areas. 


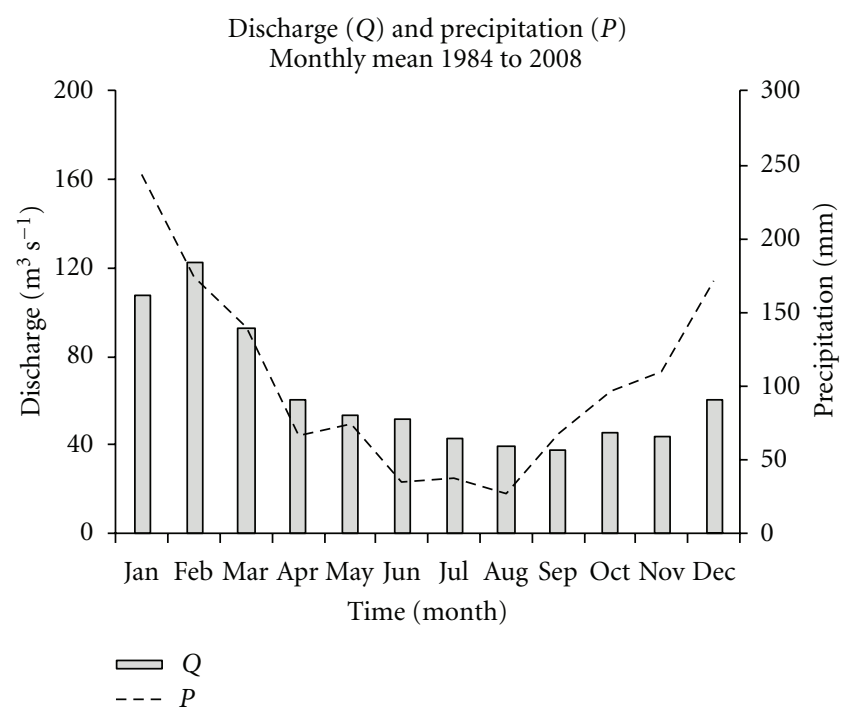

FIgURe 2: Average monthly discharge $(Q)$ and precipitation $(P)$ in the Sorocaba River basin for the 1984-2008 period.

The region of the headwaters, in Atlantic Plateau, is better preserved (60\% with original vegetation) and the Peripheral Depression region concentrated agricultural and urban areas, with $70 \%$ and $10 \%$ of its total area, respectively [8].

According to Koppen classification [9], the climate is Cwb in the upstream part and Cwa in the Peripheral Depression area, both indicating the predominance of summer rains and dry winters. Figure 2 illustrates the annual variability of the precipitation and the river discharge for the 1984-2008 period. The average calculations were performed from daily data (personal communication DAEE/CTH in 2009) for the limnimetric station 4E-001 Entre Rios $\left(23^{\circ} 01^{\prime} \mathrm{S}, 47^{\circ} 48^{\prime} \mathrm{W}\right)$ and the pluviometric station E4-019 Iperó $\left(23^{\circ} 20^{\prime} \mathrm{S}, 47^{\circ} 41^{\prime} \mathrm{W}\right)$, located in the central region of the drainage basin. The annual averages calculated for the 25-year period were $63.1 \mathrm{~m}^{3} \mathrm{~s}^{-1}$ for the discharge and $1243.1 \mathrm{~mm}$ for the precipitation, with a higher monthly average discharge in February $\left(122.1 \mathrm{~m}^{3} \mathrm{~s}^{-1}\right)$ and the lowest discharge in September $\left(37.5 \mathrm{~m}^{3} \mathrm{~s}^{-1}\right)$.

\section{Material and Methods}

The fine suspended sediments (FSS) transported by rivers are usually characterized as particles smaller than $63 \mu \mathrm{m}$ [10], whose composition is a complex mixture of organic and inorganic particles originating from various sources, such as atmospheric deposition, eroded soil and rock, and domestic and industrial sewages [11]. Eighteen FSS samples were collected at the Sorocaba River basin mouth station, from March 2009 to September 2010. The FSS concentrations were determined from $1000 \mathrm{~mL}$ of river water composite samples, collected in the left and right margins of the river and in the main axis of the current river at a $1.5 \mathrm{~m}$ depth using a singlestage sampling point [12]. From these composite samples, $300 \mathrm{~mL}$ were filtered through previously weighed cellulose membrane filters $(0.45 \mu \mathrm{m})$, and the FSS obtained plus the membrane filters were dried at $60^{\circ} \mathrm{C}$ to constant weight. The FSS concentration was quantified gravimetrically according to $(1)$ :

$$
C_{\mathrm{FSS}}=\frac{\left(m_{f}-m_{i}\right)}{V_{L}},
$$

where $C_{\mathrm{FSS}}$ is the FSS concentration $\left(\mathrm{mg} \mathrm{L}^{-1}\right), m_{f}$ the final mass of the filter $(\mathrm{mg}), m_{i}$ the initial mass filter $(\mathrm{mg})$, and $V_{L}$ the volume filtered (L).

The average FSS concentration normalized by the discharge $\left(C_{\mathrm{MNQ}}\right.$, in $\left.\mathrm{mg} \mathrm{L}^{-1}\right)$ was calculated according to the procedure established by Probst [13], as shown in (2):

$$
C_{\mathrm{MNQ}}=\frac{\sum\left(Q_{i} \times C_{i}\right)}{\sum Q_{i}}
$$

where $Q_{i}$ is the discharge measured on the sampling day $\left(\mathrm{m}^{3} \mathrm{~s}^{-1}\right), C_{i}$ the FSS concentration for the sampling day, and $\sum Q_{i}$ the sum of all discharges measured on the sampling days $\left(\mathrm{m}^{3} \mathrm{~s}^{-1}\right)$.

Additionally, river water composite samples were collected from the left and right margins of the river and in the main axis of the current river. $30 \mathrm{~L}$ of water samples are stored in polypropylene containers to obtain sufficient FSS mass for chemical characterization. After the settlement of the FSS, the recovered sediments were air-dried and sieved using a $63 \mu \mathrm{m}$ nylon mesh. The sediments retained in the sieve $(>63 \mu \mathrm{m})$ were separated and with a portion of FSS $(<63 \mu \mathrm{m})$ reserved for mineralogical analysis. Other portions of the FSS samples were calcinated at $1000^{\circ} \mathrm{C}$ to remove all the organic matter and were digested using the alkaline fusion method proposed by Samuel et al. [14]. $100 \mathrm{mg}$ of the sample was mixed with lithium tetraborate and lithium metaborate $(2: 1)$ in a platinum crucible and heated at $1000^{\circ} \mathrm{C}$ for 30 minutes. After cooling, the melt was dissolved in $20 \mathrm{~mL}$ of $\mathrm{HCl}(1 \mathrm{M})$ under agitation and heating at $40^{\circ} \mathrm{C}$, and the volume completed to $50 \mathrm{~mL}$ with MilliQ water. This analysis was performed in triplicate using the inductively coupled plasma optical emission spectrometry (ICP-OES). The limits of detection, in $\mathrm{mg} \mathrm{L}^{-1}$, were $\mathrm{Si}$ (0.020), Al (0.020), Fe (0.020), Mn (0.002), Ca (0.050), Mg (0.050), $\mathrm{Na}(0.050)$, and $\mathrm{K}(0.050)$. We controlled the purity of the chemical reagents and the blanks with bank ground measurements below the precision limits. To control the quality of the extraction process and the chemical analyses, we used the international reference material Soil-7 of the International Atomic Energy Agency (IAEA). We obtained the following average $\%$ of recovery for the extraction and analysis in triplicate: $\mathrm{Si}(91.7 \%), \mathrm{Al}(90.1 \%), \mathrm{Fe}(107.3 \%)$, Mn (101.2\%), Ca (92.3\%), Mg (89.7\%), Na (89.2\%), and K $(91.0 \%)$.

\section{Results and Discussions}

4.1. Chemical Characterization of the FSS. The chemical characterization of the FSS showed a predominance of $\mathrm{SiO}_{2}$ (48.60\%), $\mathrm{Al}_{2} \mathrm{O}_{3}$ (21.05\%), and $\mathrm{Fe}_{2} \mathrm{O}_{3}$ (8.23\%) for the analyzed elements (Table 1). Analysis of the FSS mineralogical 
TABLE 1: Major element concentrations (expressed as oxide \%) for the FSS sampled at the Sorocaba River basin mouth during the study period.

\begin{tabular}{|c|c|c|c|c|c|c|c|c|c|}
\hline \multirow{2}{*}{ Sampling date } & \multirow{2}{*}{$\begin{array}{c}\text { Discharge } \\
\left(\mathrm{m}^{3} \mathrm{~s}^{-1}\right)\end{array}$} & \multicolumn{8}{|c|}{ Major element concentrations (expressed as oxide \%) } \\
\hline & & $\mathrm{SiO}_{2}$ & $\mathrm{Al}_{2} \mathrm{O}_{3}$ & $\mathrm{Fe}_{2} \mathrm{O}_{3}$ & $\mathrm{MnO}$ & $\mathrm{CaO}$ & $\mathrm{MgO}$ & $\mathrm{Na}_{2} \mathrm{O}$ & $\mathrm{K}_{2} \mathrm{O}$ \\
\hline Mar-10-09 & 51.50 & 41.22 & 19.69 & 9.82 & 0.54 & 0.83 & 0.86 & 0.44 & 2.06 \\
\hline Apr-07-09 & 59.30 & 45.74 & 22.45 & 10.47 & 0.49 & 0.74 & 0.89 & 0.40 & 2.15 \\
\hline May-12-09 & 46.83 & 46.03 & 19.44 & 7.92 & 0.39 & 0.71 & 0.82 & 0.38 & 2.02 \\
\hline Jun-17-09 & 37.47 & 42.12 & 19.50 & 9.30 & 0.40 & 0.70 & 0.74 & 0.39 & 2.02 \\
\hline Jul-21-09 & 43.71 & 44.60 & 23.48 & 7.61 & 0.31 & 0.55 & 0.81 & 0.38 & 2.30 \\
\hline Aug-25-09 & 123.23 & 47.80 & 21.43 & 6.83 & 0.23 & 0.56 & 0.81 & 0.32 & 2.22 \\
\hline Sep-22-09 & 99.84 & 43.20 & 20.26 & 6.99 & 0.31 & 0.57 & 0.78 & 0.31 & 2.07 \\
\hline Nov-10-09 & 170.01 & 49.17 & 18.74 & 5.97 & 0.16 & 0.51 & 0.88 & 0.33 & 2.03 \\
\hline Dec-12-09 & 363.35 & 48.95 & 19.65 & 6.33 & 0.22 & 0.52 & 0.82 & 0.34 & 2.14 \\
\hline Jan-15-10 & 279.15 & 51.65 & 21.35 & 7.71 & 0.34 & 0.68 & 1.04 & 0.37 & 2.46 \\
\hline Jan-20-10 & 366.47 & 49.71 & 21.72 & 7.03 & 0.21 & 0.54 & 0.97 & 0.28 & 2.17 \\
\hline Feb-23-10 & 184.04 & 53.23 & 20.01 & 7.60 & 0.50 & 0.64 & 0.85 & 0.37 & 2.45 \\
\hline Mar-30-10 & 151.30 & 56.55 & 21.61 & 6.65 & 0.20 & 0.56 & 0.86 & 0.33 & 2.38 \\
\hline Apr-27-10 & 107.64 & 50.48 & 22.78 & 8.37 & 0.48 & 0.67 & 0.87 & 0.34 & 2.59 \\
\hline May-27-10 & 70.21 & 52.07 & 22.92 & 10.46 & 0.51 & 0.76 & 0.90 & 0.39 & 2.68 \\
\hline Jun-24-10 & 42.15 & 46.48 & 23.05 & 12.32 & 0.69 & 0.93 & 0.86 & 0.35 & 2.35 \\
\hline Jul-27-10 & 54.62 & 47.81 & 24.23 & 9.22 & 0.53 & 0.75 & 0.86 & 0.34 & 2.58 \\
\hline Sep-01-10 & 26.56 & 57.98 & 16.53 & 7.61 & 0.73 & 1.08 & 0.80 & 0.46 & 2.05 \\
\hline Average (\%) & 48.04 & 47.12 & 21.26 & 9.42 & 0.51 & 0.78 & 0.84 & 0.39 & 2.25 \\
\hline SD & 12.76 & 5.16 & 2.56 & 1.57 & 0.14 & 0.15 & 0.05 & 0.04 & 0.25 \\
\hline Average (\%) & 205.00 & 50.08 & 20.84 & 7.05 & 0.29 & 0.58 & 0.88 & 0.33 & 2.28 \\
\hline SD & 105.13 & 3.69 & 1.25 & 0.74 & 0.12 & 0.06 & 0.08 & 0.03 & 0.20 \\
\hline CV (\%) & 85.9 & 9.5 & 9.3 & 20.6 & 41.9 & 22.3 & 8.1 & 12.3 & 9.7 \\
\hline
\end{tabular}

The average and the standard deviations (SD) are shown for two periods, low water and high water, and the coefficient of variation (CV) for the study period (all samples). The bold font represents the low water period and the light face font represents the high water period.

TABLE 2: Mobility estimation of the elements during the rockalteration process in the Sorocaba River basin.

\begin{tabular}{lccc}
\hline \multirow{2}{*}{ Element } & $\begin{array}{c}\text { Crust } \\
\text { Ct }(\%)\end{array}$ & \multicolumn{2}{c}{ Sorocaba River Basin } \\
& 6.93 & 11.14 & \% loss $(-)$ or gain $(+)$ \\
\hline $\mathrm{Al}$ & 3.59 & 6.40 & 0 \\
$\mathrm{Fe}$ & 0.07 & 0.31 & 11 \\
$\mathrm{Mn}$ & 1.42 & 0.27 & -88 \\
$\mathrm{Na}$ & 4.50 & 0.49 & -93 \\
$\mathrm{Ca}$ & 1.64 & 0.52 & -80 \\
$\mathrm{Mg}$ & 2.44 & 1.88 & -52 \\
$\mathrm{~K}$ & 27.50 & 22.71 & -49 \\
$\mathrm{Si}$ & & & \\
\hline
\end{tabular}

composition, performed by X-ray diffraction, confirmed this predominance, because a significant amount of quartz, kaolinite, and magnetite was found in the fine fraction $(<63 \mu \mathrm{m})$, and quartz, potassium feldspar, and plagioclase were found in the larger fraction $(>63 \mu \mathrm{m})$. The concentrations of Fe and $\mathrm{Al}$ in the FSS are attributed to the presence of oxides that originated from the red lateritic soils that cover the basin. This observation was also verified for the Piracicaba River basin [15], another important tributary of the Tietê River.
The coefficients of variation showed a greater dispersion for $\mathrm{Mn}(41.9 \%)$, $\mathrm{Ca}(22.3 \%)$, and $\mathrm{Fe}(20.6 \%)$ and around $10 \%$ for other elements. These results reflect an apparent seasonal influence, which may be linked to the different origins of the FSS [16]. Some studies showed that the chemical composition of river sediments can provide information about the rock alteration processes and particularly the origin of the FSS particles. This chemical information may indicate element mobilities during the weathering process at the drainage basin scale [16-18].

In the Sorocaba River basin, this mobility is estimated considering the ratio between the FSS chemical composition $(C t)$ and the mean composition of surface rocks of the crust, described by Martin and Meybeck [16]. We applied a normalization, by the respective concentrations of $\mathrm{Al}$, assuming its conservative behavior during the rockalteration processes [19], according to (3):

$$
\left\{\left[\frac{(C t / A l)_{\text {sed }}}{(C t / A l)_{\text {crust }}}\right] \times 100\right\}-100 .
$$

The results in Table 2 indicate a conservative behavior for $\mathrm{Fe}$ and a significant gain for $\mathrm{Mn}$. Oxides and hydroxides secondary minerals of Fe and Mn may be formed after the rock-alteration processes, especially when predominant land use is agriculture [19]. $\mathrm{Na}, \mathrm{Ca}, \mathrm{Mg}$, and $\mathrm{K}$ levels indicate 
reductions from $49 \%$ to $93 \%$ and illustrate a high degree of mobility that can be related to silicate-alteration processes [19]. Such processes release these elements in the same range that is already found in the alteration process of carbonates and evaporites, which are more easily weathered [20]. For instance, $\mathrm{Si}$, the main element in the alteration of silicate rocks, showed a significant reduction of $49 \%$. This may be related to the solubilization in the rock-alteration process where the mass loss in rocks is associated with Si removal [21].

During the rock-alteration process in the drainage basin, the evolution of primary to secondary minerals is associated with a relative enrichment in $\mathrm{Al}$ and $\mathrm{Fe}$ and depletion in $\mathrm{Si}$. The increase in $\mathrm{Al}_{2} \mathrm{O}_{3}$ and $\mathrm{Fe}_{2} \mathrm{O}_{3}$ concentrations to the detriment of $\mathrm{SiO}_{2}$ provides an indication of the rockalteration degree, expressed by the $R$ index, according to (4) [22]. The $R$ index allows comparison of the rock alteration intensity between drainage basins a lower $R$ value indicates a higher rock-alteration process in the drainage basin [23]:

$$
R=\frac{\mathrm{SiO}_{2(\%)}}{\left(\mathrm{Al}_{2} \mathrm{O}_{3}+\mathrm{Fe}_{2} \mathrm{O}_{3}\right)_{(\%)}} .
$$

The $R$ value calculated for the Sorocaba River basin was 1.7, indicating an intense rock-alteration process when compared with other drainage basins, such as the Patagonia rivers (2.9 to 4.3) in Argentina, the Ill (3.1) and Garonne (5.1) rivers in France, and the Sebou river (2.8 to 4.8 ) in Africa [23]. However, this result was similar to that observed for the Piracicaba River basin (1.8) [24], another important tributary of the Middle Tietê basin.

This rock-alteration process was also assessed by the chemical maturity index (ChM), established by Konta [25], which relates the $\mathrm{Al}$ with the cationic bases (5). The longer a rock is altered, it becomes more mature and the higher the ChM index:

$$
\mathrm{ChM}=\frac{\mathrm{Al}_{2} \mathrm{O}_{3(\%)}}{\left(\mathrm{Na}_{2} \mathrm{O}+\mathrm{MgO}+\mathrm{CaO}\right)_{(\%)}} .
$$

The ChM index, calculated for the Sorocaba River basin, was significant (11.1) and similar to the one reported by Mortatti and Probst [15] for the Piracicaba River basin (10.4) and higher than that observed for the Patagonia rivers (2.0 to 4.8 ), the Ill (4.6), the Garonne (5.1), and the Sebou (3.4 to $5.3)$ rivers [23], confirming the high rock-alteration degree determined by $R$ index.

\subsection{Estimate of the Suspended Load of Quick Surface Runoff.} The quick surface runoff is directly associated with mechanical erosion processes that occur in a drainage basin. It is responsible for the transport of particulate matter into the river channel throughout the drainage basin. The particulate matter load that reaches the river channel by quick surface runoff is diluted by river waters from the subsurface and hypodermic and underground compartments, whose particulate matter load can be considered negligible [22]. The relationship responsible for the mechanical erosion between the surface and subsurface reservoirs can be described according to $(6)[22,26]$. Using the relationship between total discharge
TABle 3: Estimation of the particulate matter load of quick surface runoff $\left(\mathrm{Cr}, \mathrm{mg} \mathrm{L}^{-1}\right)$ depending on the total concentration of FSS $\left(C t, \mathrm{mg} \mathrm{L}^{-1}\right)$ and the respective total discharge $\left(\mathrm{Qt}, \mathrm{m}^{3} \mathrm{~s}^{-1}\right)$ observed at the Sorocaba River mouth, in the study period, with respective averages and standard deviations.

\begin{tabular}{lccc}
\hline Sampling date & $Q t\left(\mathrm{~m}^{3} \mathrm{~s}^{-1}\right)$ & $C t\left(\mathrm{mg} \mathrm{L}^{-1}\right)$ & $C r\left(\mathrm{mg} \mathrm{L}^{-1}\right)$ \\
\hline Mar-10-09 & 51.50 & 16.33 & 43.11 \\
Apr-07-09 & 59.30 & 20.67 & 54.24 \\
May-12-09 & 46.83 & 25.33 & 67.16 \\
Jun-17-09 & 37.47 & 14.33 & 38.46 \\
Jul-21-09 & 43.71 & 46.50 & 123.69 \\
Aug-25-09 & 123.23 & 54.33 & 139.90 \\
Sep-22-09 & 99.84 & 45.33 & 117.21 \\
Nov-10-09 & 170.01 & 145.00 & 371.56 \\
Dec-12-09 & 363.35 & 87.17 & 221.86 \\
Jan-15-10 & 279.15 & 47.67 & 121.54 \\
Jan-20-10 & 366.47 & 101.50 & 258.33 \\
Feb-23-10 & 184.04 & 37.83 & 96.85 \\
Mar-30-10 & 151.30 & 178.00 & 456.84 \\
Apr-27-10 & 107.64 & 51.00 & 131.66 \\
May-27-10 & 70.21 & 22.67 & 59.25 \\
Jun-24-10 & 42.15 & 14.50 & 38.64 \\
Jul-27-10 & 54.62 & 28.83 & 75.92 \\
Sep-01-10 & 26.56 & 17.67 & 48.60 \\
\hline Average (\%) & 126.52 & 73.55 & 188.41 \\
SD & 108.62 & 44.96 & 114.67 \\
\hline
\end{tabular}

and quick surface runoff presented by Fernandes et al. [27] for the 1984-2008 period (7), it has been possible to estimate the particulate matter load transported by the Sorocaba River associated with the quick surface runoff (Table 3):

$$
C t \times Q t=C r \times Q r,
$$

where $C t$ is the total concentration of FSS transported by the total discharge $(Q t)$ and $C r$ is the particulate matter load concentration transported by quick surface runoff $(Q r)$ :

$$
Q r=0.3952 Q t-0.8423 \text {. }
$$

During dry periods, both preceding the rise of the water level (March-July 2009) and after the recession (May-September 2010), the flow-weighted average concentrations calculated for $\mathrm{Cr}$ were similar, with values of 64.61 and $57.97 \mathrm{mg} \mathrm{L}^{-1}$, respectively. In the flood period, from December 2009 to January 2010, the flow-weighted average concentration was approximately four times higher (231.03 $\mathrm{mg} \mathrm{L}^{-1}$ ). It should be emphasized that the highest $\mathrm{Cr}$ concentration occurred in March 2010 (456.84 $\mathrm{mg} \mathrm{L}^{-1}$ ), during the receding period of Sorocaba River, being associated with erosion processes of the river banks, which is difficult to document.

4.3. Dynamics of Fine Sediments in Suspension. The FSS concentrations seem to be influenced by the variation of the Sorocaba River discharge during the study as illustrated in 


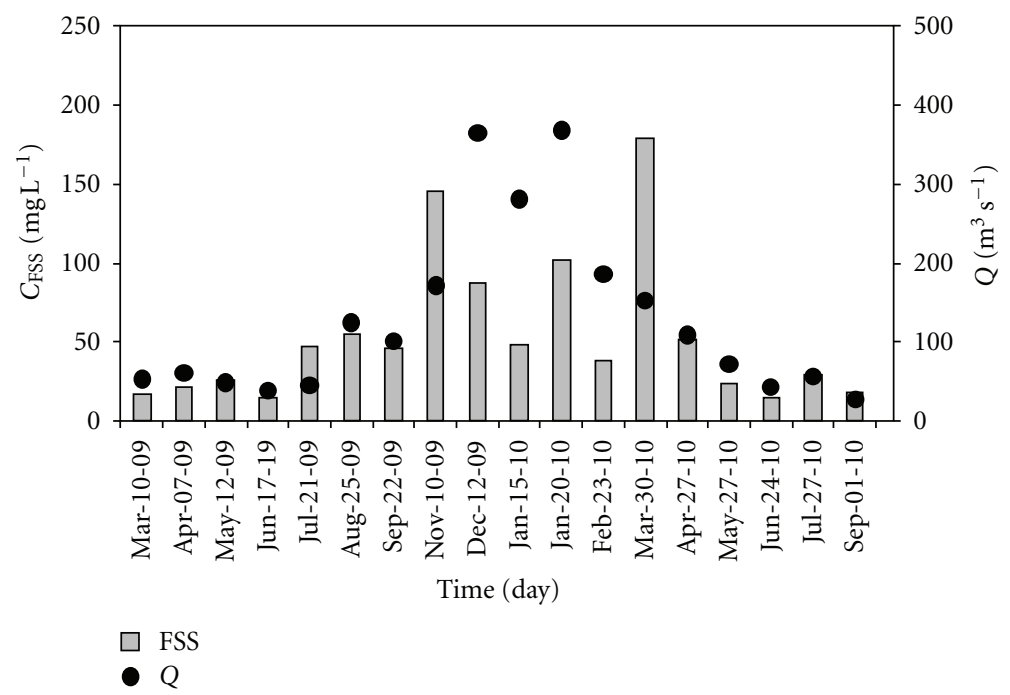

FIgURE 3: Temporal variability of the FSS concentration $\left(\mathrm{mg} \mathrm{L}^{-1}\right)$ and respective discharges $\left(Q, \mathrm{~m}^{3} \mathrm{~s}^{-1}\right)$ at the mouth of Sorocaba River basin.

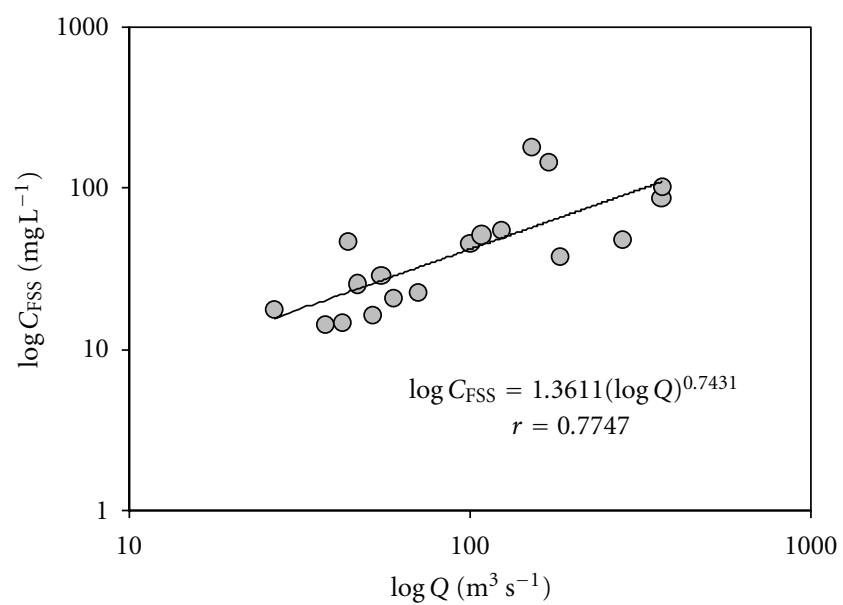

FIGURE 4: Logarithmic correlation between the FSS concentration $\left(\mathrm{mg} \mathrm{L}^{-1}\right)$ and the respective discharges $\left(\mathrm{Q}, \mathrm{m}^{3} \mathrm{~s}^{-1}\right)$ at the Sorocaba River basin mouth.

Figure 3. We emphasize that during the rise of the water level (November 2009) and low river levels (March 2010), the highest FSS peaks are observed in the Sorocaba River.

The relationship between the suspended sediment concentration $(C)$ and stream discharge $(Q)$ can be evaluated with the use of the logarithmic model $\left(C=a Q^{b}\right)[28]$, where the $a$ and $b$ values vary between drainage basins, reflecting the different physical, climatic, and hydrological characteristics of each basin contribution area. For most rivers of the world, the $b$ exponent is positive, indicating the increase in suspended sediment concentration caused by an increased discharge [29]. The logarithmic correlation model established for the Sorocaba River, using our sampling strategy, was significant at $1 \%$ (Figure 4 ).
The $b$ exponent values obtained for the Sorocaba River (0.7431) were lower than those observed in the literature, which range between 1 and 2, according to the drainage basin characteristics [22]. This difference is confirmed when compared to the results obtained for the Tietê (1.7788) and the Piracicaba (1.4954) Rivers, two other rivers in the Middle Tietê basin region [30].

Although the annual hydrological regime, with the seasonal distribution of precipitation and discharge, as well as the land use (predominantly agricultural) of the Sorocaba River is similar to Tietê and Piracicaba Rivers [31], the comparison of the $b$ exponent indicates a different distribution pattern of the suspended sediment concentration according to the discharge variation of these three rivers, which can be partly explained by distinct physical characteristics of the drainage basins, mainly associated with the relief and the arrangement and contribution of the tributaries. The dispersion of points observed in Figure 4 indicates the possible influence of the dynamic processes on the remobilization and sedimentation, characteristic to small and medium sized rivers $[2,22,29,32]$.

4.4. Transport of FSS. The sediment load carried by the river is evaluated in terms of the FSS, assuming that suspended load represents approximately $90 \%$ of the total sediment river flow [33]. Thus, the total transport of river sediments $\left(T\right.$, in $\left.\mathrm{ta}^{-1}\right)$ was estimated considering the average FSS concentration normalized by the discharge $\left(C_{\mathrm{MNQ}}\right.$, in $\left.\mathrm{mg} \mathrm{L}^{-1}\right)$ and the average discharge of the study period $\left(Q_{m}\right.$, in $\mathrm{m}^{3} \mathrm{~s}^{-1}$ ), using the stochastic method [34], according to (8):

$$
T=C_{\mathrm{MNQ}} \times Q_{m} \times f,
$$

where the $f$ factor corresponds to the mass and time correction in the calculation of total transport for results in tons per year and is equal to 31.536 . 
The total transport of FSS calculated for the Sorocaba River mouth was $293 \times 10^{3} \mathrm{ta}^{-1}$, which corresponds to a specific transport of $55.70 \mathrm{t} \mathrm{km}^{-2} \mathrm{a}^{-1}$. This value is in accordance with that reported for the Tietê and the Piracicaba Rivers, 59.60 and $55.50 \mathrm{t} \mathrm{km}^{-2} \mathrm{a}^{-1}$, respectively [30]. Compared to international drainage basins of the same magnitude, the specific transport of FSS observed for the Sorocaba River is similar to the Chena River, USA $\left(5125 \mathrm{~km}^{2}\right.$ and $\left.54,75 \mathrm{t} \mathrm{km}^{-2} \mathrm{a}^{-1}\right)$ and the Chaudiere River, France $\left(5805 \mathrm{~km}^{2}\right.$ and $56,58 \mathrm{t} \mathrm{km}^{-2} \mathrm{a}^{-1}$ ) [35].

4.5. Specific Physical Degradation. The physical degradation degree of a drainage basin, understood as the mechanical erosion rate in meters per million years, can be evaluated as a function of specific transport of FSS $\left(F_{\mathrm{FSS}}\right.$, in $\left.\mathrm{t} \mathrm{km}^{-2} \mathrm{a}^{-1}\right)$ and mean density of soils $\left(d\right.$, in $\left.\mathrm{t} \mathrm{m}^{-3}\right)$ of the basin studied [36], according to (9):

$$
\mathrm{EM}=\frac{F_{\mathrm{FSS}}}{d} .
$$

The mean density of the Sorocaba River basin soils was determined by the classical method reported by Blake and Hartge [37], the core method, considering three distinct portions of the drainage basin established in accordance with the distribution of predominant soil types. In the headwater region, where the red-yellow Latosol prevails, the mean density soil was estimated at $1.24 \pm 0.02 \mathrm{t} \mathrm{m}^{-3}$; in the middle part, with the predominance of red Podzols the mean density for this soil was $1.65 \pm 0.01 \mathrm{t} \mathrm{m}^{-3}$; and at the downstream part of the basin, with a predominance of red Latosols, the mean density soil was $1.53 \pm 0.01 \mathrm{t} \mathrm{m}^{-3}$. The mean density calculated from the Sorocaba River basin soil was $1.47 \pm$ $0.01 \mathrm{t} \mathrm{m}^{-3}$.

The mechanical erosion rate calculated for the Sorocaba River basin is $37.99 \mathrm{~m} \mathrm{Ma}^{-1}$. Compared to other drainage basins with similar areas and land use predominantly agricultural, the physical degradation degree of the Sorocaba River basin was similar to that observed by Bortoletto Junior [30] for the Tietê $\left(42.6 \mathrm{~m} \mathrm{Ma}^{-1}\right)$ and the Piracicaba (37.0 $\mathrm{m} \mathrm{Ma}^{-1}$ ) Rivers, five times higher than the degradation of the Congo River, with $7.4 \mathrm{~m} \mathrm{Ma}^{-1}$ [38], and thirteen times higher than the degradation of the Niger River, with values ranging from 2.4 to $3.4 \mathrm{~m} \mathrm{Ma}^{-1}$ [39]. These differences could be related to land use processes in the respective drainage basins, particularly the agricultural practices of each region, such as soil management and types of crops, and other human activities developed there.

\section{Conclusions}

A focus of this study is to derive a better understanding of the mechanical erosion processes that occur in a tropical river basin of southeastern Brazil, where the predominant land use is agricultural, with increased urbanization in the past decade. The FSS load is influenced by the variation in discharge river during the study period, with the same seasonal effect. This situation is emphasized by suspended matter load associated with the quick surface runoff, which was four times higher in the high water period than in dry periods.

However, the FSS chemical characterization for major oxides does not indicate that seasonal influence and the variability of concentrations observed during the study period were related to the mobility of these elements during rock weathering process. The mechanical erosion in the Sorocaba River basin was $55.70 \mathrm{t} \mathrm{km}^{-2} \mathrm{a}^{-1}$, representing a physical degradation rate of $37.88 \mathrm{~m} \mathrm{Ma}^{-1}$, in the same magnitude of the other two major rivers that comprise the Middle Tiete basin.

\section{Acknowledgments}

The authors thank the Fundação de Apoio à Pesquisa do Estado de São Paulo (Process 08/57104-4 and 08/09369-9) and the Conselho Nacional de Desenvolvimento Científico e Tecnológico (Process 134169/2009-3) for the financial support granted, as well as the Centro Tecnológico de Hidráulica e Recursos Hídricos of the Departamento de Águas e Energia Elétrica, for providing the time series of daily discharge and rainfall data for the Sorocaba River basin.

\section{References}

[1] M. R. L. Siviero and E. M. Coiado, "A produção de sedimentos a montante de uma seção do rio Atibaia associada à descarga sólida transportada," in Proceedings of the 13th Simpósio Brasileiro de Recursos Hídricos, Belo Horizonte, 1999.

[2] F. F. B. Ferraz and J. Mortatti, "Avaliação do processo erosivo mecânico em bacia subtropical desenvolvida pela análise de sedimentos finos em suspensão," Geociências, vol. 21, no. 1-2, pp. 113-120, 2002.

[3] F. F. Pruski, L. N. Rodrigues, and D. D. Silva, "Modelo hidrológico para estimativa do escoamento superficial em áreas agrícolas," Revista Brasileira de Engenharia Agrícola e Ambiental, vol. 5, no. 2, pp. 301-307, 2001.

[4] Instituto Brasileiro de Geografia e Estatística-IBGE, "Dados do Censo 2010 publicados no Diário Oficial da União do dia 04/11/2010," 2010, http://www.ibge.gov.br/censo2010/dados_ divulgados/index.php/uf=35.

[5] J. L. S. Ross and I. C. Moroz, Mapa Geomorfológico do Estado de São Paulo, Laboratório de Geomorfologia/Departamento de Geografia/FFLCH-USP, Laboratório de Cartografia Geotécnica-Geologia Aplicada-IPT, FAPESP, Mapas e Relatórios, São Paulo, Brazil, 1997.

[6] J. B. Oliveira, M. N. Camargo, M. Rossi, and B. Calderano Filho, MaPa Pedológico do Estado de São Paulo: Legenda Expandida, Instituto Agronômico, Campinas, São Paulo, and Rio de Janeiro: Embrapa-Solos, Rio de Janeiro, Brazil, 1999.

[7] M. M. Perrota, E. D. Salvador, R. C. Lopes et al., Mapa Geológico do Estado de São Paulo, Scale 1:750,000, Programa Geologia Brasil-PGB, CPRM, São Paulo, Brasil, 2005.

[8] Instituto de Pesquisas Tecnológicas-IPT, Atualização do Relatório de Situação dos Recursos Hídricos 1995 da Bacia do Sorocaba e Médio Tietê (Relatório Zero) Como Subsídio à Elaboração do Plano de Bacia, vol. 1, (Relatório Técnico no. 80 401-205), Agrupamento de Geologia Aplicada ao Meio Ambiente-AGAMA/Divisão de Geologia-DiGeo/Instituto de Pesquisas Tecnológicas-IPT, Paulo, Brazil. 
[9] W. P. Köppen, Climatologia: Com um Estúdio de los Climas de la Tierra, Fondo de Cultura Economica, Español. México, 1st edition, 1948.

[10] D. E. Walling and P. W. Moorehead, "The particle size characteristics of fluvial suspended sediment: an overview," Hydrobiologia, vol. 176-177, no. 1, pp. 125-149, 1989.

[11] E. T. Degens, S. Kempe, and J. E. Richey, Biogeochemistry of Major World Rivers, John Wiley \& Sons, Chichester, UK, 1990.

[12] J. Mortatti, Erosão na Amazônia: processos, modelos e balanço [Sci thesis], Escola Superior de Agricultura "Luiz de Queiroz", Universidade de São Paulo, Piracicaba, São Paulo, Brazil, 1995.

[13] J. L. Probst, "Géochimie et hydrologie de l'érosion continentale. Mécanisms, bilan global actuel et fluctuations au cours des 500 derniers millions d'annés," Sciences Géologiques, no. 94, p. 161, 1992.

[14] J. Samuel, R. Rouault, and Y. Besnus, "Analyse multiémentaire standardisée des materiaux géologiques en spectrométrie d'émission par plasma a couplage inductif," Analusis, vol. 13, no. 7, pp. 312-317, 1985.

[15] J. Mortatti and J. L. Probst, "Characteristics of heavy metals and their evaluation in suspended sediments from Piracicaba river basin (São Paulo, Brazil)," Revista Brasileira De Geociências, vol. 40, no. 3, pp. 375-379, 2010.

[16] J. M. Martin and M. Meybeck, "Elemental mass-balance of material carried by major world rivers," Marine Chemistry, vol. 7, no. 3, pp. 173-206, 1979.

[17] R. F. Stallard, "Weathering and erosion in the humid tropics," in Physical and Chemical Weathering in Geochemical Cycles, A. Lerman and M. Meybeck, Eds., pp. 225-246, Kluwer Academic, 1988.

[18] J. I. Drever, The Geochemistry of Natural Watersed, PrenticeHall, New Jersey, NJ, USA, 2nd edition, 1988.

[19] D. E. Canfield, "The geochemistry of river particulates from the continental USA: major elements," Geochimica et Cosmochimica Acta, vol. 61, no. 16, pp. 3349-3365, 1997.

[20] M. Meybeck, "Global chemical weathering of surficial rocks estimated from river dissolved loads," American Journal of Science, vol. 287, no. 5, pp. 401-428, 1987.

[21] J. M. Edmond, M. R. Palmer, C. I. Measures, B. Grant, and R. F. Stallard, "The fluvial geochemistry and denudation rate of the Guayana Shield in Venezuela, Colombia, and Brazil," Geochimica et Cosmochimica Acta, vol. 59, no. 16, pp. 33013325, 1995.

[22] J. L. Probst and A. Bazerbachi, "Transports en solution et en suspension par la Garonne supérieure," Scence Géologique Bulletin, vol. 39, pp. 79-98, 1986.

[23] L. Leleyter, Spéciation chimique des éléments majeurs, traces et des terres rares dans les matières en suspension et dans lês sédiments de found dês cours d'eau: application aux fleuves de Patagonia (Argentine), à La Piracicaba (Brésil), à Sebou (Maroc) et à I'lll (France) [Ph.D. thesis], Université Louis Pasteur, Strasbourg, France, 1998.

[24] J. Mortatti, M. C. Bernardes, J. L. Probst, and L. Leleyter, "Composição química dos sedimentos fluviais em suspensão na bacia do rio Piracicaba: extração seletiva de elementos traço," Geochimica Brasiliensis, vol. 16, no. 2, pp. 123-141, 2002.

[25] J. Konta "Mineralogy and chemical maturity of suspended matter in major world rivers sampled under the Scope/Unep project," in Transport of Carbon and Minerals in Major World Rivers, Part 3, E. T. Degens, Ed., vol. 58, pp. 569-592, Mitt. Geology Paläontology, Ins. Universität Hamburg, Scope/Unep Sonderband, 1985.
[26] J. L. Probst and N. Sigha, "Estimation de l'écoulement superficiel et de as charge en suspension sur quelques grands bassins fluviaux du monde," Comptes Rendus de L'Acadadémie des Sciences, vol. 309, no. 4, pp. 357-363, 1989.

[27] A. M. Fernandes, M. B. Nolasco, and J. Mortatti, "Estimativa do escoamento superficial rápido e sua carga em suspensão com a aplicação de do modelo de separação de hidrogramas com filtros numéricos: bacia do rio Sorocaba-SP," Geociências, vol. 29, no. 1, pp. 49-57, 2010.

[28] M. Meybeck, Les fleuves et le cycle géochimique des elements [Sci. thesis], Université de Paris VI, Paris, France, 1984.

[29] J. L. Probst, "Dissolved and suspended matter transported by the Girou River (France): mechanical and chemical erosion rates in a calcareous molasse basin," Hydrological Sciences Journal/Journal des Sciences Hydrologiques, vol. 31, no. 1, pp. 61-79, 1986.

[30] J. M. Bortoletto Junior, Características hidrogeoquímicas e processos erosivos mecânicos e químicos nas bacias de drenagem dos rios Tietê e Piracicaba [Ph.D. thesis], Centro de Energia Nuclear na Agricultura, Universidade de São Paulo, São Paulo, Brasil, 2004.

[31] J. Mortatti, M. J. Bortoletto Junior, L. C. E. Milde, and J. L. Probst, "Hidrologia dos rios Tietê e Piracicaba: séries temporais de vazão e hidrogramas de cheia," Revista Ciência e Tecnologia, vol. 12, no. 23, pp. 55-97, 2004.

[32] J. Mortatti, J. L. Probst, and M. J. Bortoletto Junior, "Piracicaba river basin: mechanical and chemical erosions," Geociências, vol. 22, no. 1, pp. 75-81, 2003.

[33] D. E. Walling and D. Fang, "Recent trends in the suspended sediment loads of the world's rivers," Global and Planetary Change, vol. 39, no. 1-2, pp. 111-126, 2003.

[34] J. L. Probst, P. Amiotte-Suchet, and Y. Tardy, "Global continental erosion and fluctuations of atmospheric $\mathrm{CO}_{2}$ consumed during the last 100 years," in Proceedings of the 7th International Symposium on Water-Rock Interaction, pp. 483486, 1992.

[35] M. Meybeck, L. Laroche, H. H. Dürr, and J. P. M. Syvitski, "Global variability of daily total suspended solids and their fluxes in rivers," Global and Planetary Change, vol. 39, no. 1-2, pp. 65-93, 2003.

[36] J. Mortatti, R. L. Victória, and Y. Tardy, "Balanço de alteração e erosão química na bacia amazônica," Geochimica Brasiliensis, vol. 11, no. 1, pp. 2-13, 1997.

[37] G. R. Blake and K. H. Hartge, "Bulk densityin," in Method of Soil Analysis. Part 1. Physical and Mineralogical Methods, A. Klute, Ed., pp. 363-375, American Society of Agronomy, Soil Science Society of America, Madison, Wis, USA, 2nd edition, 1986.

[38] R. R. Nkounkou and J. L. Probst, "Hydrology and geochemistry of the Congo river system," Mitt. Geology Paläontology, Ins. Universität Hamburg, Scope/Unep Sonderband, vol. 64, pp. 483-508, 1987.

[39] J. L. Boeglin and J. L. Probst, "Physical and chemical weathering rates and $\mathrm{CO}_{2}$ consumption in a tropical lateritic environment: the upper Niger Basin," USDA Forest ServiceGeneral Technical Report RMRS-GTR, vol. 148, no. 3-4, pp. 137-156, 1998. 

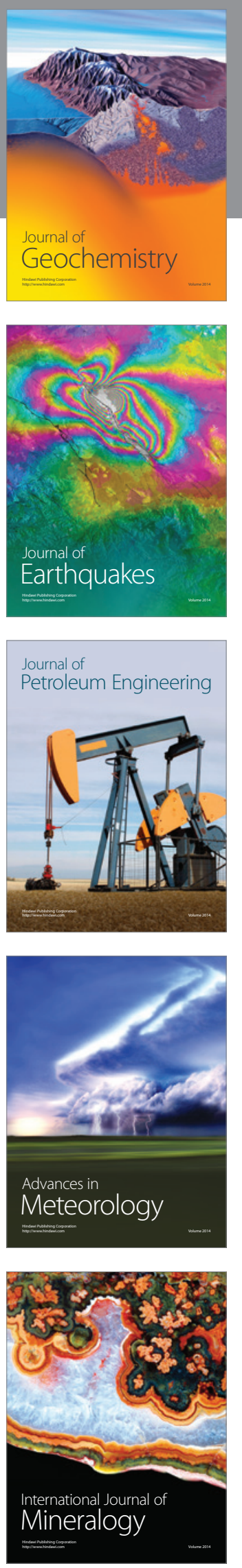
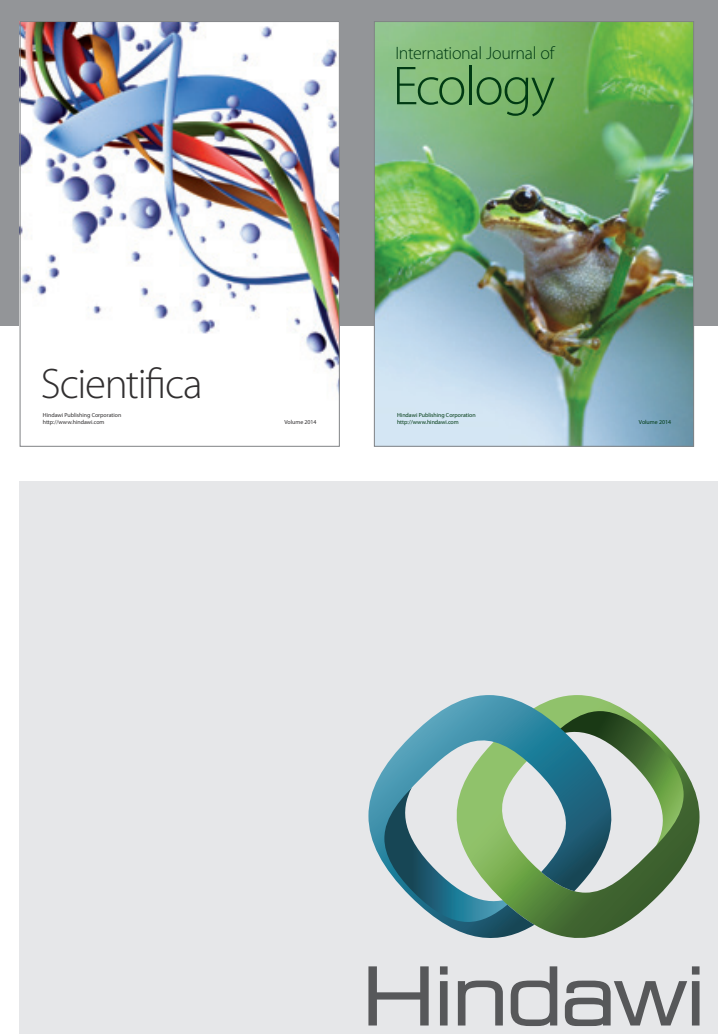

Submit your manuscripts at http://www.hindawi.com
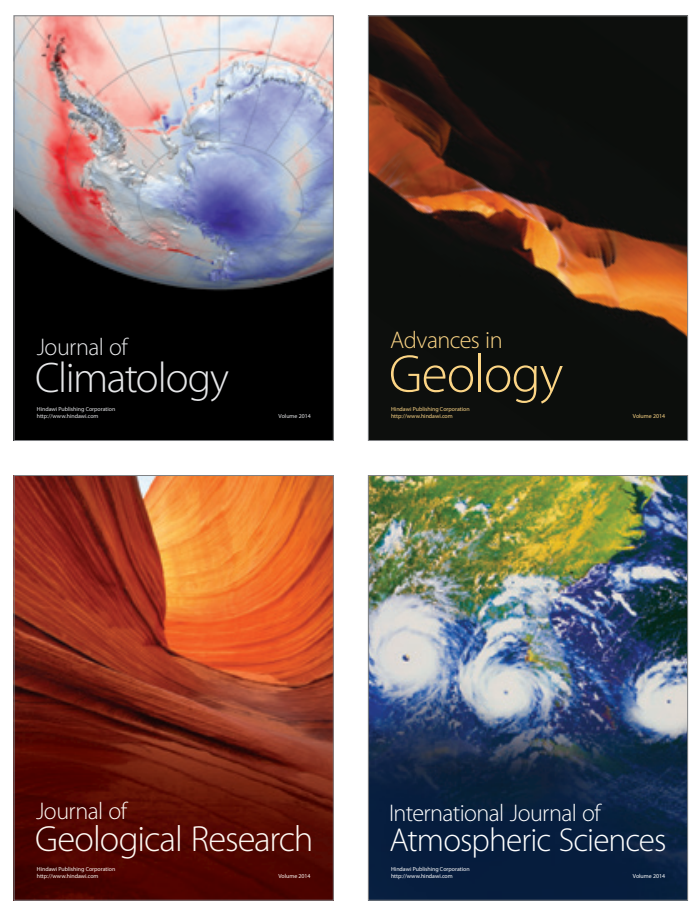
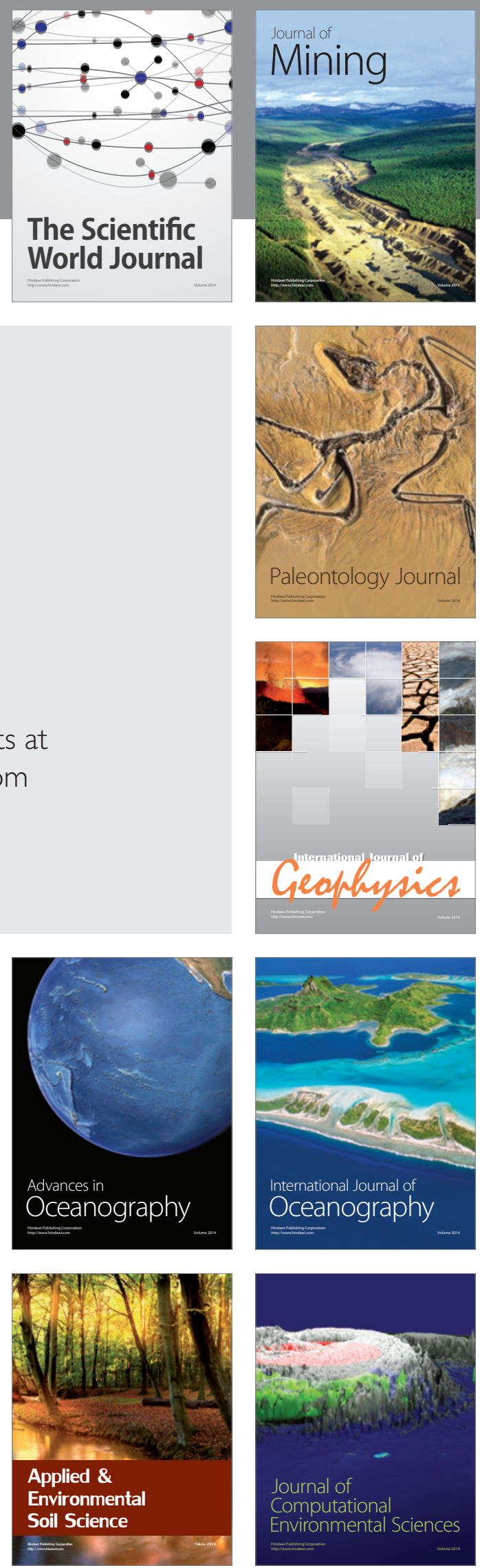